\title{
Penyuluhan Pola Hidup Bersih Sehat (PHBS) Di SDN 01 Cimanggis Bojonggede Kabupaten Bogor
}

\author{
Emilda ${ }^{1}$, Muslihatul Hidayah ${ }^{2}$ \\ 1Prodi Pendidikan Biologi, FMIPA Universitas Indraprasta PGRI, Indonesia \\ Email: emilda1430@gmail.com \\ 2Prodi Informatika, FTIK Universitas Indraprasta PGRI, Indonesia \\ Email: muslihatulhidayah@gmail.com
}

Accepted: 25-07-2020

\begin{abstract}
PHBS in schools is an important activity in order to prepare young people to be aware of self and environmental health. Because the habits that are built from an early age will build a person's behavior patterns in his adult life. The targets of this activity are students and teachers. This activity is carried out with 2 methods, that are counseling students and presentations, secondly demonstrations in front of the teaches. The results of the activities showed that teachers and students already had general knowledge about PHBS. While the indicator for each PHBS point is not yet understood. Counseling activities are still minimal implemented by both schools and related agencies. Even though the built of PHBS characters requires repeated socialization. Counseling is more effective by using games, video shows and live demonstrations. Teachers and students are more enthusiastic about listening than just lecturing. Besides that the school need to complete supporting facilities and infrastructure to facilitate the application of PHBS in schools. And to realize it, it takes the contribution of other parties, especially the government.
\end{abstract}

Keywords: school PHBS, healthy students, counseling, demonstration

\begin{abstract}
Abstrak
PHBS di sekolah termasuk kegiatan yang penting dalam rangka menyiapkan generasi muda untuk sadar terhadap kesehatan pribadi dan lingkungan. Sebab kebiasaan yang dibangun sejak usia dini akan membentuk pola tingkah laku seseorang di masa dewasanya. Sasaran kegiatan ini adalah para siswa dan guru. Kegitan ini dilaksanakan dengan 2 metode yaitu penyuluhan kepada siswa serta presentasi dan demonstrasi di depan guru. Hasil kegiatan menunjukkan para guru dan siswa sudah memiliki pengetahuan umum tentang PHBS. Sedangkan indikator setiap poin PHBS belum dipahami. Kegiatan penyuluhan masih minim dilaksanakan baik oleh sekolah maupun dari dinas terkait. Padahal pembentukan karakter PHBS membutuhkan sosialisasi yang berulang. Pelaksanaan penyuluhan lebih efektif dengan menggunakan permainan, penayangan video serta demonstrasi langsung. Guru dan siswa lebih antusias mendengarkan dibanding penyampaian ceramah saja. Selain itu Sekolah perlu melengkapi sarana dan prasarana pendukung untuk memudahkan penerapan PHBS di sekolah. Dan untuk merealisasikannya dibutuhkan kontribusi pihak lain terutama pemerintah.
\end{abstract}

Kata kunci : PHBS sekolah, siswa sehat, penyuluhan, demonstrasi

\section{PENDAHULUAN}

Terwujudnya generasi sehat merupakan modal besar bagi negara untuk mewujudkan cita-citanya.

Sebab SDM yang berkualitas merupakan subjek dan sekaligus 
objek dalam pembangunan. Sejatinya dibutuhkan upaya yang serius, berkelanjutan dan sungguhsungguh untuk merealisasikannya mulai dari usia dini. Pemerintah seharusnya memainkan peran penting untuk mewujudkannya mulai dari upaya promotif, preventif, dan kuratif. Faktanya menurut data Riset Kesehatan Dasar (Riskesdas) tahun 2007 bahwa di Indonesia rumah tangga yang mempraktekan perilaku hidup bersih dan sehat (PHBS) baru mencapai $38,7 \%$ dari target $70 \%$ (Depkes, 2008). PHBS sendiri termasuk upaya preventif untuk meminimalisasi kasus penyakit.

Menurut data, anak-anak usia balita dan anak-anak yang dirawat di Puskesmas dan rumah sakit di Kabupaten Bogor, masih didominasi oleh penyakit-penyakit menular seperti infeksi saluran pernafasan atas akut, nasofaringitis akut dan yang ketiga penyakit kulit dan jaringan subkutan serta diare dan gastroenteritris (Dinas Kesehatan Kabupaten Bogor, 2019). Hal ini menjadi indikator bahwa kualitas lingkungan yang ditempati masyarakat masih rendah dan belum memenuhi standar kesehatan yang layak. Ditambah pula kesadaran masyarakat yang masih minim terhadap kebersihan lingkungan dan pola hidup bersih sehat.
Gambaran lingkungan hidup ini terlihat diantaranya dari pendataan Tempat-Tempat Umum (TTU) dan Tempat Pengolahan Makanan (TPM). Dari 3.994 lokasi TTU yang berupa sarana pendidikan, sarana kesehatan dan hotel, baru 929 atau $23,26 \%$ saja yang sudah memenuhi syarat kesehatan. Sedang 76,74\% TTU di kabupaten Bogor belum memenuhi syarat kesehatan. Begitupula TPM yang berupa jasa boga, rumah makan/restoran, Depot Air Minum serta makanan jajanan. Sekitar 75,61\% dari 3621 buah TPM juga belum memenuhi syarat kesehatan. Cakupan rumah sehat mencapai 90,24\%, cakupan layak sanitasi baru 70,44\%, cakupan keluarga terhadap akses air minum berkualitas baru 69,38\%. Sementara pelaksanaan PHBS tergambar dari kategori rumah tangga sehat baru mencapai 55,43\%, dan sisanya masih terkategori rumah tangga tidak sehat (Dinas Kesehatan Kabupaten Bogor, 2019)

Perilaku hidup bersih sehat pada dasarnya merupakan sebuah upaya untuk menularkan pengalaman mengenai pola hidup sehat melalui individu, kelompok ataupun masyarakat luas dengan jalur-jalur komunikasi sebagai media berbagi informasi. Ada berbagai informasi yang dapat dibagikan seperti materi edukasi guna menambah pengetahuan serta 
meningkatkan sikap dan perilaku terkait cara hidup yang bersih dan sehat (Direktorat Promosi Kesehatan dan Pemberdayaan Masyarakat Kementerian Kesehatan RI, 2016)

Ada beberapa tatanan PHBS yang melibatkan beberapa elemen dan merupakan bagian dari tempat beraktivitas dalam kehidupan sehari-hari. Diantaranya PHBS di sekolah. PHBS di sekolah menjadi kegiatan yang penting dalam rangka menyiapkan generasi muda sejak dini yang sadar terhadap kesehatan. Sebab kebiasaan yang dibangun sejak usia dini akan membentuk pola tingkah laku seseorang di masa dewasanya.

Proses pendidikan merupakan upaya sistematis dan bersifat kontinyu untuk membentuk karakter seseorang. Baik pendidikan formal maupun informal dengan penyuluhan, pelatihan dsb. Namun untuk menerapkan karakter PHBS dipengaruhi sejumlah faktor seperti kebiasaan di rumah, lingkungan masyarakat, kondisi sekolah, peran guru dsb. (Julianti et al., 2018)

Sasaran kegiatan pengabdian masyarakat ini adalah pada tatanan PHBS di sekolah. Kegiatan ini dilaksanakan dengan memberdayakan siswa, guru dan masyarakat lingkungan sekolah untuk mau melakukan pola hidup sehat guna menciptakan pribadi siswa dan lingkungan sekolah yang sehat. Manfaat PHBS di sekolah adalah agar dengan terciptanya siswa yang sehat serta lingkungan yang bersih berdampak pada kondusifitas proses belajar mengajar. Dan akhirnya berpengaruh pula pada meningkatnya prestasi belajar siswa (Taryatman, 2016). Sekolah yang sehat dengan anggota komunitas yang berperilaku hidup bersih dan sehat dapat mencegah sekolah sebagai titik penularan atau sumber berbagai penyakit.

Hasil observasi awal ke lokasi mitra di daerah Bojonggede, diketahui bahwa belum pernah dilakukan sosialisasi PHBS di sekolah ini. Termasuk indikator PHBS belum pernah disampaikan secara menyeluruh. Namun perilaku membuang sampah pada tempatnya serta membawa tempat makan dan minum sendiri sudah mulai dibiasakan oleh sekolah sebagai bentuk pembelajaran untuk menjaga lingkungan.

Infrastruktur pendukung untuk membangun karakter PHBS belum tersedia lengkap di sekolah seperti belum tersedia keran cuci tangan, jumlah toilet masih kurang, kantin sehat juga belum ada. Akan tetapi pihak sekolah memiliki keinginan besar untuk merealisasikan pola hidup bersih dan sehat ini. Hal ini terlihat telah ada berbagai inisiatif 
pribadi dari guru bersama siswa untuk menerapkan karakter PHBS dengan kondisi seadanya.

Berdasarkan hal ini maka dianggap perlu untuk mensosialisasikan pentingnya penerapan Pola Hidup Bersih dan Sehat baik kepada guru dan siswa dengan tujuan agar terwujud pemahaman dan kesadaran untuk mewujudkan lingkungan sekolah yang bersih sehingga mendukung proses belajar mengajar menjadi nyaman. Serta terwujud siswa yang sehat dan memiliki daya tahan tubuh yang kuat.

\section{METODE PELAKSANAAN}

Kegiatan ini dilakukan dengan 2 metode yaitu:

1. Melakukan penyuluhan berupa pemaparan materi mengenai konsep PHBS kepada siswa dan guru. Kegiatan penyuluhan disertai demo singkat tentang teknik cuci tangan serta diselingi permainan untuk siswa terkait pengetahuan makanan sehat dan makanan yang membahayakan tubuh.

2. Melakukan presentasi kepada guru tentang konsep PHBS disertai demo pembuatan hand sanitizer berbahan alami.

\section{HASIL DAN PEMBAHASAN}

Kegiatan pengabdian masyarakat dilaksanakan di SDN 01
Cimanggis Kecamatan Bojong Gede Kabuapaten Bogor mulai bulan September 2019-Januari 2020 Sasaran yang dituju adalah siswa dan para guru.

Kondisi lingkungan yang sehat belum terlihat di lingkungan SDN 01 Cimanggis Bojonggede yang dijadikan mitra kegiatan ini. Disamping karena pihak sekolah sedang melakukan pembangunan beberapa infrastruktur, juga fasilitas penunjang kebersihan belum memadai. Tumpukan peralatan yang telah rusak tersimpan di pojok-pojok ruang kelas seperti bekas tempat sampah yang sudah tidak terpakai. Padahal peralatan bekas ini bisa menjadi sarang nyamuk.

Penyuluhan dilakukan dengan dengan cara eksplorasi disertai penanaman pengetahuan yang benar tentang konsep PHBS di tatanan sekolah yang terdiri atas 8 poin. Hasil eksplorasi ini menunjukkan baik guru maupun siswa baru mengetahui poin-poin PHBS secara umum. Akan tetapi indikator dari setiap poin PHBS belum dipahami.

Seperti tata cara mencuci tangan yang benar. Terdapat indikator mencuci tangan yang benar yaitu: 1) Membasahi tangan seluruhnya dengan air mengalir; 2) Menggosok sabun ke telapak punggung tangan dan sela jari-jari; 3) Membersihkan 
daerah bawah kuku; 4) Membilas tangan dengan air bersih mengalir dan 5) Mengeringkan tangan dengan handuk/tissu atau keringkan dengan udara.
Selain menjelaskan tata cara cuci tangan, disertai dengan demonstrasi bagaimana melakukannya secara benar. Hanya saja demo tidak dilakukan langsung karena keterbatasan sarana.

Suasana penyampaian materi terlihat pada gambar 1 dan 2 berikut.

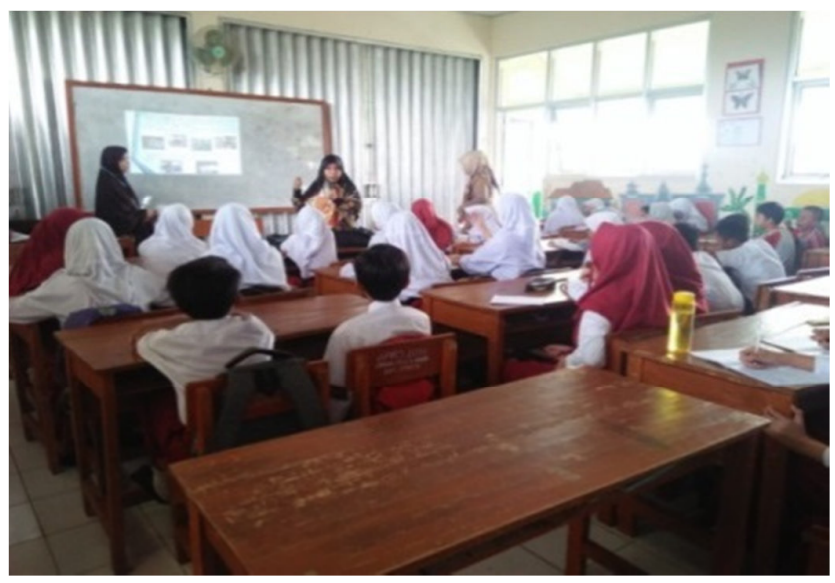

Gambar 1. Penyuluh sedang menyampaikan materi

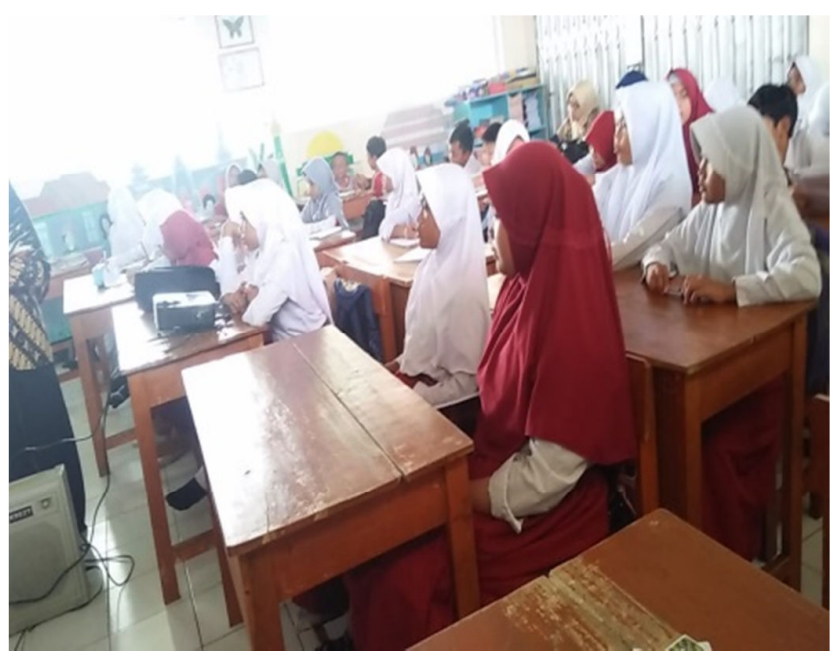

Gambar 2: Siswa memperhatikan penyampaian materi

Begitu pula poin kedua tentang membuang sampah pada tempatnya. Secara umum kebiasaan membuang sampah pada tempatnya telah mulai terbentuk pada siswa. Akan tetapi belum dilakukan pemilahan antara sampah organik dan anorganik. 
Padahal dengan fenomena pengelolaan sampah hari ini, seharusnya pengetahuan ini sudah disampaikan kepada siswa yang didukung dengan penyediaan tempat sampah untuk kedua tipe sampah ini.

Berkaitan dengan konsumsi jajanan sehat, umumnya para siswa sudah mengetahui contoh makanan sehat dan berbahaya Namun pada prakteknya, masih sulit untuk mengimplementasikannya yang disebabkan faktor ekonomi orang tua. Ditambah pula warung yang menjual jajanan di sekitar sekolah belum bisa ditertibkan untuk tidak menjual makanan yang mengandung senyawa-senyawa tambahan yang berbahaya. Sementara sekolah belum bisa menyediakan kantin khusus sekolah.

Padahal penyakit degeneratif sudah mulai banyak ditemukan pada usia remaja yang disebabkan kebiasaan mengkonsumi makanan yang mengandung senyawa berbahaya seperti rhodamin B, Methanil yellow, amaranth, boraks, formalin, siklamat, sakarin, dan benzoat (Mukhlis Catio, 2013). Bahkan makanan yang kurang baik secara kualitas maupun kuantitas akan menyebabkan gizi kurang. Keadaan gizi kurang dapat menyebabkan gangguan pertumbuhan dan perkembangan, khusus pada perkembangan dapat mengakibatkan perubahan struktur dan fungsi otak (Gunawan et al., 2016).

Sedang penggunaan jamban secara bersih dan sehat belum terlaksana secara benar dikalangan siswa. Seperti membiasakan buang air kecil di WC dan menyiramnya sampai bersih. Bahkan fasilitas jamban di sekolah juga belum memadai baik dari sisi jumlah maupun standar jamban/kamar mandi sehat

$\begin{array}{rcc}\text { Poin } & \text { berikutnya } & \text { tentang } \\ \text { olahraga } & \text { secara } & \text { teratur. }\end{array}$
Pelaksanaannya pun masih minim. Para siswa berolahraga baru sebatas mengikuti pelajaran di sekolah. Diluar itu belum terbentuk kebiasaan olahraga secara teratur.

Sedangkan poin tidak merokok, seluruh siswa tidak ada yang merokok dan sudah mengetahui bahaya dari merokok. Begitupula melakukan kerja bakti bersama belum terbangun di kalangan siswa kecuali pada waktu-waktu tertentu yang dimobilisasi oleh sekolah.

Belum terlaksananya PHBS secara optimal di sekolah ini juga disebabkan tidak tersedianya fasilitas pendukung. Seperti kran cuci tangan dan sabunnya, kamar mandi yang cukup dan sehat, tempat sampah untuk dua jenis sampah dsb. Padahal keberadaan fasilitas yang memenuhi prasyarat 
akan ikut mendorong siswa menerapkan PHBS dan begitupula sebaliknya (Raharjo \& KM, 2014).

Disamping penyuluhan, juga dibuat permainan bagi siswa. Model permainan termasuk salah satu cara yang dinilai efektif untuk digunakan dalam penyuluhan kepada anak-anak. Penyampaian materi pendidikan akan lebih efektif bila disampaikan dalam suasana yang menyenangkan seperti melalui permainan (Sutriyanto et al., 2016).

Penyuluhan kesehatan dengan menggunakan metode permainan akan menimbulkan ketertarikan siswa sehingga dengan mudah dapat mengerti serta mampu mengingat pesan kesehatan yang disampaikan.

Pada kegiatan ini siswa diajak melakukan permainan tebak kata dan gambar yang tujuannya mengenal komposisi bahan makanan dengan gizi seimbang. Seperti makanan yang mengandung karbohidrat, protein, buah dan sayur. Serta makanan yang mengandung senyawa berbahaya seperti yang mengandung bahan pengawet, pewarna dan pemanis buatan

Para siswa antusias mengikuti permainan ini dan melaksanakan instruksi dari tim penyuluh. Dari hasil permainan terlihat umumnya siswa telah tepat menempatkan makanan sesuai kelompok makanannya. Menempatkan makanan sehat sesuai nutrisi yang dikandungnya dan makanan berbahaya sesuai kandungan senyawanya. Hal ini menunjukkan sudah ada pengetahuan dan pemahaman yang mereka dapatkan.

Para siswa juga bisa menjelaskan kegunaan nutrisi makanan tersebut bagi tubuh. Akan tetapi belum bisa mempraktekkannya dalam kehidupan sehari-hari terutama karena faktor ekonomi dan belum menjadi kebiasaan.

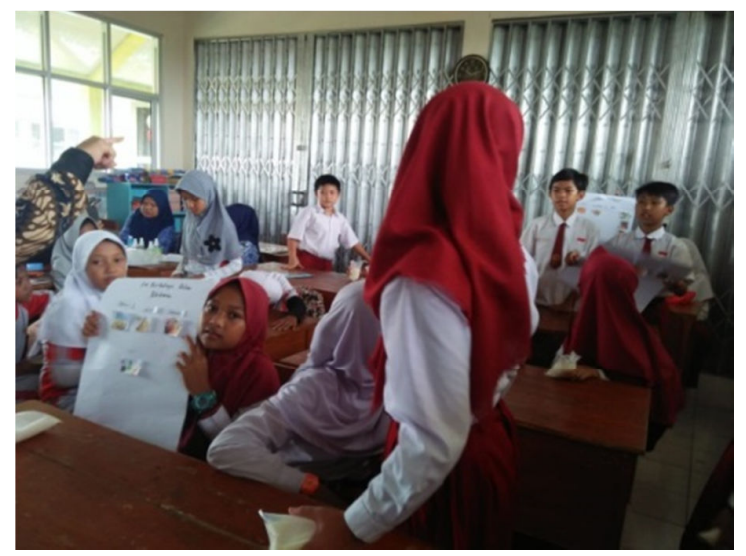

Gambar 3. Suasana Siswa Mengikuti Permainan 
Penanaman poin-poin PHBS harusnya dilakukan secara berkelanjutan. Cara yang digunakan bisa beberapa metode. Diantaranya mengadakan penyuluhan secara berkala, memasukkan materi PHBS kedalam kurikulum pembelajaran atau kegiatan ekstrakurikuler, atau membentuk Usaha Kesehatan Sekolah (UKS) yang berperan untuk menanamkan poin-poin PHBS secara rutin (Simbolon \& Simorangkir, 2018).

Sementara untuk guru, selain pemberian materi juga dilakukan demonstrasi langsung pembuatan hand sanitizer berbahan alami dengan menggunakan bahan utamanya ekstrak aloe vera. Proses pembuatannya langsung dipraktikkan didepan para guru seperti terlihat pada gambar 4 dibawah.

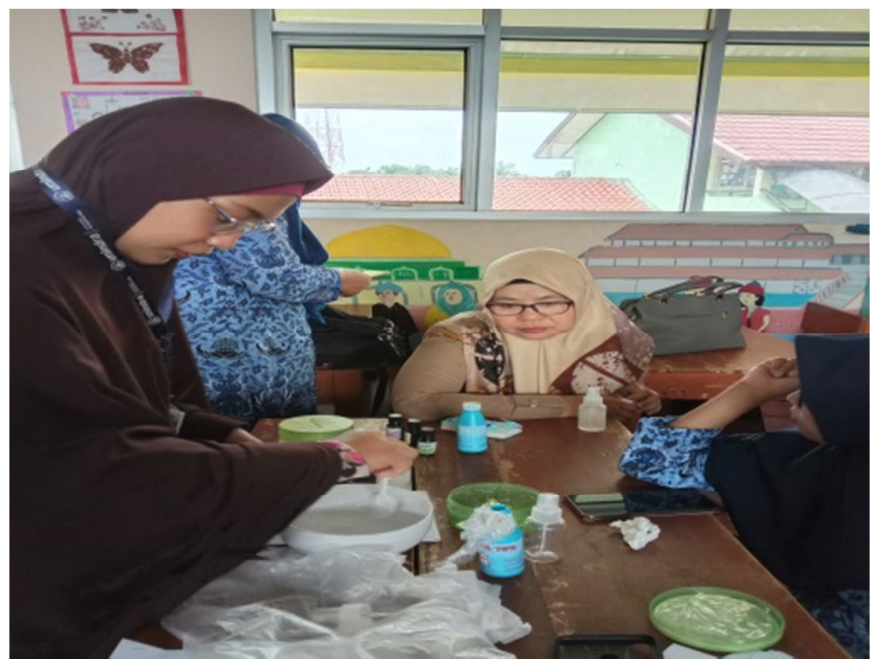

Gambar 4. Demo Pembuatan Hand Sanitizer

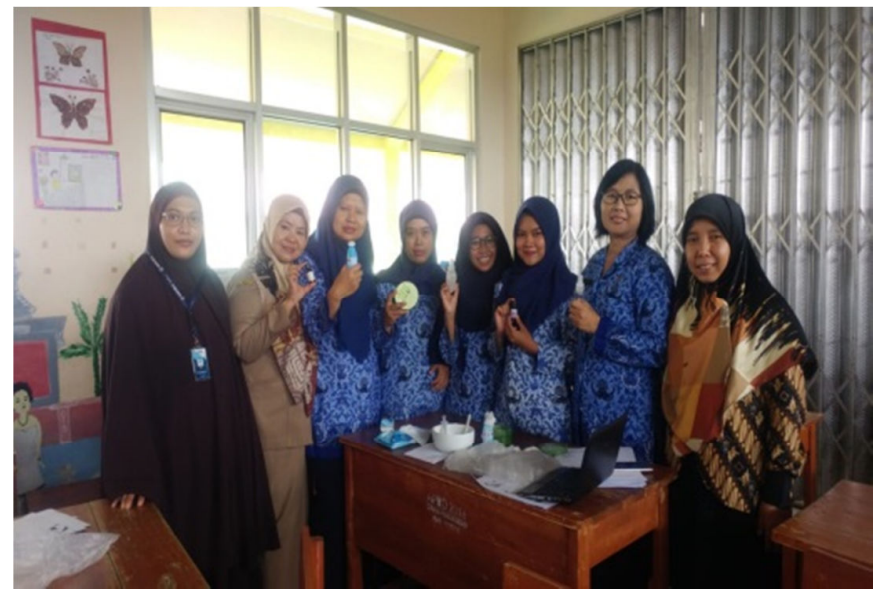

Gambar 5. Bersama guru yang membawa hand sanitizer 
Para guru terlihat antusias mengikutinya bahkan sebagian merekam proses pembuatan. Sebagai oleh-oleh, kepada masingmasing guru dibagikan produk hand sanitizer ini. Terlihat pada gambar 5 para guru menunjukkan hand sanitizer yang sudah dibuat.

\section{PENUTUP}

Penyuluhan dan sosialisasi PHBS sangat diperlukan di tataan sekolah dalam rangka mewujudkan generasi yang sehat dan lingkungan belajar mengajar yang bersih. Namun di SDN 01 Cimanggis Bojonggede kegiatan ini belum pernah dilaksanakan.

Berdasarkan hasil kegiatan diketahui guru dan siswa belum memahami indikator-indikator PHBS secara utuh dan benar. Melaksanakan penyuluhan yang dikombinasikan dengan permainan bagi siswa dan demonstrasi langsung pembuatan sebuah produk, lebih menarik daripada sebatas ceramah.

Untuk mendukung penerapan PHBS di sekolah dibutuhkan sarana dan fasilitas pendukung seperti kran cuci tangan, kamar mandi yang sehat dan jumlah yang cukup, kantin sekolah sehat, dsb. Kegiatan ini perlu dilakukan secara berkala baik mandiri oleh sekolah atau mengajak instansi lain yang terkait.

\section{DAFTAR PUSTAKA}

Depkes, R. I. (2008). Riset kesehatan dasar 2007. Jakarta: Badan Penelitian Dan Pengembangan Kesehatan Republik Indonesia.

Dinas Kesehatan Kabupaten Bogor. (2019). Buku Profil Dinas Kesehatan Kabupaten Bogor tahun 2018.

Direktorat Promosi Kesehatan dan Pemberdayaan Masyarakat Kementerian Kesehatan RI. (2016). PHBS.

Http:/ /Promkes.Kemkes.Go.Id /Phbs.

Gunawan, G., Fadlyana, E., \& Rusmil, K. (2016). Hubungan status gizi dan perkembangan anak usia 1-2 tahun. Sari Pediatri, 13(2), 142-146.

Julianti, R., Nasirun, M., \& Wembrayarli, W. (2018). Pelaksanaan Perilaku Hidup Bersih dan Sehat (Phbs) di Lingkungan Sekolah. Jurnal Ilmiah Potensia, 3(2), 76-82.

Mukhlis Catio. (2013). Peran Pendidikan dalam Mengatasi Masalah Kesehatan Remaja. Ikatan Dokter Anak Indonesia. Ikatan Dokter Anak Indonesia.

Raharjo, A. S., \& KM, S. I. S. (2014). Hubungan natara Pengetahuan, Sikap, dan Ketersediaan Fasilitas di Sekolah dalam Penerapan PHBS Membuang Sampah Pada Tempatnya (Studi di Sekolah Dasar Negeri Banjarsari 02 Kecamatan Gabus Kabupaten Pati). Unnes Journal of Public Health, 3(1). 
Simbolon, P., \& Simorangkir, L.

(2018). Penerapan UKS dengan

PHBS di wilayah kerja

Puskesmas Pancur Batu

Kabupaten Deli Serdang. Jurnal

Kesehatan Lingkungan Indonesia, 17(1), 16-25.

Sutriyanto, K., Raksanagara, A. S., \& Wijaya, M. (2016). Pengaruh

Permainan Kartu Kasugi

terhadap Peningkatan

Pengetahuan Perilaku Hidup

Bersih dan Sehat pada Siswa.

Jurnal Sistem Kesehatan, 1(4).

Taryatman, T. (2016). Budaya hidup bersih dan sehat di sekolah dasar untuk membangun genersi muda yang berkarakter. TRIHAYU: Jurnal Pendidikan Ke$S D-A n, 3(1)$. 